\title{
Analysing quality deficiencies of three potato cultivars during the storage period
}

\author{
Alexandru BUNA, ${ }^{1 *}$ Erzsébet DOMOKOS, ${ }^{2}$ \\ Livia Daniela DONESCU, ${ }^{3}$ Elena Maria IANOȘI ${ }^{3}$ \\ ${ }^{1}$ Department of Horticulture, Faculty of Technical and Human Sciences, \\ Sapientia Hungarian University of Transylvania, Târgu-Mureş, \\ e-mail: bunasanyi@yahoo.com (*corresponding author) \\ ${ }^{2}$ Department of Fundamental Pharmaceutical Sciences, Pharmaceutical Botany, \\ Cell Biology and Microbiology, University of Medicine and Pharmacy Târgu-Mureș, \\ e-mail: domokosrzsbet@gmail.com \\ ${ }^{3}$ National Institute of Research and Development for Potato and Sugar Beet, Brașov, \\ e-mail: daniela.donescu@ potato.ro, maria.ianosi@potato.ro
}

Manuscript received July 24, 2016; revised August 15; accepted September 16

\begin{abstract}
The aim of this work was to assess quality deficiencies in three potato cultivars (Christian, Roclas, and Cumidava) during the storage period. According to the results, the Roclas presented the highest level of susceptibility to pathogens; this, however, can be attributed to the dry rot that causes greater damage in this cultivar. No significant positive correlations between the plant's vegetative parameters and the most dangerous diseases and pests in Christian were detected. There was a significant positive correlation between the biomass of the tubers and the silver scurf blemish disease, respectively between tuber numbers and dry rot in Cumidava and significant positive correlations between tuber numbers and the silver scurf blemish disease, between biomass of the tubers and dry rot, respectively between tuber numbers and wireworm larvae at Roclas. Altogether, we can conclude that the most susceptible cultivar was Roclas followed by Cumidava, while the least susceptible was the Christian cultivar.
\end{abstract}

Keywords: Cultivar Christian, Cumidava, Roclas, susceptibility, vegetation, pests

\section{Introduction}

Potato is a high-value crop with complex production, storage, and utilization, and therefore, adequate prevention practices are necessary to obtain a healthy 
product [1]. It belongs to crops infected by many diseases that severely affect both above- ground and below-ground plant organs [2]. The development of more effective methods of controlling potato pests and diseases remains an important task facing agricultural scientists today [3].

Quality deficiencies on potato tubers are on the increase and several reasons have been suggested to explain these deficiencies [6]. One reason can be the continuous increase in the use of ecological products (with much lower amounts of pesticides), leading to an increasing occurrence of pests and diseases [7, 8]. The increasing quality standard of markets may also influence tuber deficiencies: in 1980 , around $70 \%$ of potatoes were sold unwashed; today, over $90 \%$ are washed [6]. The use of resistant varieties is probably the cheapest and the most effective method against diseases and pests. However, it is not always necessary to breed for a very high level of resistance. Incomplete resistance has often given an adequate level of control in the field [7], [9]. Although many potato cultivars have been produced world-wide, there is a continuing need for new improved cultivars with high level of durable disease and pest resistance, acceptable yield quantity, and superior quality demanded by processors and supermarkets [10].

The aim of this work was to assess the quality deficiencies that appear on three potato cultivars during the storage period. This is the first step in the development of potato breeding aimed at addressing the present and future requirements for healthier, higher-quality food, while addressing suitability for ecological agriculture [11].

\section{Materials and methods}

The experiment was carried out on the research field of the National Institute of Research and Development for Potato and Sugar Beet, Brașov, Romania, Central Europe. The following three cultivars were tested: Christian, Roclas, and Cumidava, all developed at the above mentioned Institute. All cultivars were cultivated under the same field conditions and within a 50 ha area. The soil was chernozem with $\mathrm{pH} 6$, containing $30 \%$ loam and $4.5 \%$ humus. The soluble phosphorus content was $50 \mathrm{ppm}$, while the soluble potassium content exceeded 100 ppm. Fertilization was applied uniformly to all cultivars with $700 \mathrm{~kg} / \mathrm{ha}$ NPK (nitrogen, phosphorus, and potassium).

\section{Cultivar description}

Samples were collected at the seedling stage in April and May and from fruiting plants in August and October 2013. We collected young leaves (the topmost fully differentiated leaf), old leaves (the $6-8^{\text {th }}$ leaf counted from top to bottom), young fruits having yellow or green pericarps, biologically ripe, fully 
coloured fruits and peduncles of ripe fruits. In addition, young roots and stem samples were also analysed, the latter being taken $15 \mathrm{~cm}$ below the top.

Cultivar Christian

Genealogy: KE. 53 x CLEOPATRA

Maturity: medium early variety.

Tubers: oval tuber, red skin, yellow flesh.

Plant: medium developed stems, well-developed foliage, semi-erect; medium sensitive to late blight on leafs and tubers; medium resistant to PVY; sensitive to PLRV; resistant to wart disease (Synchytrium endobioticum).

Starch content: $17.0 \%$, good cooking quality; cooking type B; suitable for early and summer-autumn consumption.

Biological yield capacity: 70.6 t/ha $[11,12,13]$.

Cultivar Cumidava

Genealogy: ROESLAU x DESIREE

Maturity: medium late variety.

Tubers: round-oval tuber, red skin, yellow flesh.

Plant: thick stems, well-developed foliage, erect; medium sensitive to late blight on leafs and tubers; very resistant to PVY; resistant to PLRV; resistant to wart disease. Starch content: $20.0 \%$, good cooking quality; cooking type A/B; suitable for autumn-winter consumption.

Biological yield capacity: 70.6 t/ha $[11,12,13]$.

Cultivar Roclas

Genealogy: HB 8 x GRANDIFOLIA

Maturity: medium early variety.

Tubers: oval tuber, yellow skin, yellow flesh.

Plant: thick stems, semi-erect, robust; medium resistant to blight on leafs and tubers; medium resistant to PVY; resistant to PLRV; resistant to wart disease.

Starch content: $17.0 \%$, good cooking quality; cooking type B; suitable for early and summer-autumn consumption and processing (chips).

Biological yield capacity: 65.9 t/ha $[11,14]$.

All cultivars were planted on March 31, 2013, with 38,000 plants/ha, $35 \mathrm{~cm}$ between plants and $75 \mathrm{~cm}$ between rows. The first plantlets appeared on May 03 
and the full flowering period was between June 13 and 23. No extremities in temperature and precipitation were detected during the 2013 vegetation period in the area. The overall climate conditions were ideal for potato cultivation in 2013. The storage of tubers was processed under new and modern storage system conditions with all parameters controlled. Storage phases of equalization, wound healing, cooling, holding, and reconditioning were followed, with optimal conditions of $7-10^{\circ} \mathrm{C}$ temperature, $95-98 \%$ relative humidity and $\mathrm{CO}_{2}$ maintained at the lowest possible level.

\section{Data collection}

Analyses were made on plants during the 2014 vegetation period in July-August in order to determine the relationships between the possible pests, diseases, and physiological problems that may infect cultivars in storage after harvest.

For each cultivar, four blocks of $40 \mathrm{~m}^{2}$ study area each (a total of 12 blocks) were selected randomly, in the middle of the field, to avoid the possibility of side effects from field margins. All plants from each $40 \mathrm{~m}^{2}$ area were then measured. Observations on foliage and shoots were repeated 3 times until July 31 for each cultivar. Plant height, total shoots, total leaves and foliage, and the plants' green biomass were assessed. Infection with Phytophthora infestans was assessed on green parts.

After July 31, all plants from the 12 blocks were collected and carried to a laboratory where the following data were collected: dry shoot numbers, dry leaves number, and tuber numbers; biomass of the upper parts of the plants, biomass of the roots and stolons, and biomass of the tubers. All collected tubers were examined on the basis of the eleven external and nine internal signs used under storage conditions. These observations were carried out until all plants from the experimental blocks were assessed (the total study surface being $480 \mathrm{~m}^{2}$ ).

From each cultivar, 1000 tubers/month were randomly selected and examined during the storage period (December 2013-February 2014). Data from eleven external signs were collected and noted: three diseases (bacterial ring rot (Clavibacter michiganensis ssp. sepedonicus), common scab (Streptomyces scabies), and silver scurf blemish disease (Helminthosporium solani)), one pest (wireworms (larvae of Agriotes ssp.)), six physiological problems (the growing of small tubers on the main tuber (secondary growths), green colour, sprouting, drying, tuber distortion, exfoliation)), and mechanical injury.

Besides external signs, the data of nine internal symptoms were also collected: bacterial ring rot, late blight ( $P$. infestans), potato gangrene (Phoma exigua var. exigua, P. exigua var. foveata), dry rot (Fusarium ssp.), bacterial soft rot/blackleg (Erwinia ssp.), wireworms, black and brown spots, and mechanical injury. This process was repeated 3 times for each cultivar during the entire storage period. 


\section{Data analysis}

For the data assessed, the ANOVA test was used, and to determine statistically significant differences the Duncan post-hoc test was performed. First, all factors provoking damage were compared separately (i.e. damages caused by silver scurf at Roclas compared with damages caused by the same pathogen at Christian and Cumidava). Then, accumulative analyses were made, in which symptoms were classified and analysed according to their provoking factors: pathogens (bacteria, fungi), pests (wireworms), physiological phenomena, and mechanical injuries. The average proportions of diseases and pest and the average values of data on 1,000 tubers were considered for analysis. Pearson correlations between the plants' vegetative parameters and the most common and dangerous diseases and pests infecting particular plant organs during storage were calculated. These were: correlations between tuber numbers, biomass of the tubers, and the silver scurf blemish disease (H. solani); correlations between tuber numbers, biomass of the tubers, number of leaves and shoots per cultivar at full vegetation, the biomass of the green parts of the plants, and late blight ( $P$. infestans); correlations between tuber numbers, biomass of the tubers, and dry rot (Fusarium ssp.); also correlations between tubers number, biomass of the tubers, and wireworms (larvae of Agriotes ssp.). Significant positive correlations between plant parameters, diseases, and pest were calculated and significances computed in SPSS Statistics. Average values of vegetative data and average proportions of diseases and pest on 1,000 tubers/assessment data/cultivars were considered for the analyses, and results were presented in the table.

\section{Results and discussions}

The studied cultivars did not present significant external signs of bacterial ring rot disease. There were also no signs of secondary growth, green colour, or exfoliated tubers. The mean proportions of the affected tubers per cultivar observed on the base of external signs are presented in Table 1. It can be observed that the common scab affected all cultivars to a very high level, sometimes up to $100 \%$. ANOVA revealed that there were significant differences between cultivars regarding the appearance of quality deficiencies (Table 2). Roclas presented a significantly lower proportion of infected tubers with silver scurf than Christian and Cumidava (Duncan test, $p=0.006$ ). Wireworms, however, preferred, in a significantly higher proportion, the Roclas tubers to the Cumidava (Duncan test, 
$p=0.04)$ and the proportion of dried tubers was also significantly higher in Roclas than in Christian (Duncan test, $p=0.05$ ) (Table 2).

Table 1. The proportions of affected tubers per cultivar observed on the base of external signs during the storage period

\begin{tabular}{|c|c|c|c|}
\hline \multirow{3}{*}{$\begin{array}{l}\text { Observed } \\
\text { external signs }\end{array}$} & \multicolumn{3}{|c|}{ Cultivars } \\
\hline & Christian & Cumidava & Roclas \\
\hline & \multicolumn{3}{|c|}{ Mean proportions of affected tubers (\%) } \\
\hline Common scab & $\begin{array}{l}100 \\
\text { SD: } 0.0\end{array}$ & $\begin{array}{l}86.6 \\
\text { SD: } 11.5\end{array}$ & $\begin{array}{l}93.3 \\
\text { SD: } 11.5\end{array}$ \\
\hline Silver scurf & $\begin{array}{l}80 \\
\text { SD: } 0.0\end{array}$ & $\begin{array}{l}76.6 \\
\text { SD: } 5.7\end{array}$ & $\begin{array}{l}16.6 \\
\text { SD: } 28.8\end{array}$ \\
\hline Wireworms & $\begin{array}{l}22.5 \\
\text { SD: } 4.3\end{array}$ & $\begin{array}{l}10 \\
\text { SD: } 0.0\end{array}$ & $\begin{array}{l}46.6 \\
\text { SD: } 23.0\end{array}$ \\
\hline Sprouting & $\begin{array}{l}0.6 \\
\text { SD: } 1.1\end{array}$ & $\begin{array}{l}5.6 \\
\text { SD: } 3.7\end{array}$ & $\begin{array}{l}1.6 \\
\text { SD: } 1.5\end{array}$ \\
\hline Dried tubers & $\begin{array}{l}0 \\
\text { SD: } 0.0\end{array}$ & $\begin{array}{l}1 \\
\text { SD: } 1.0\end{array}$ & $\begin{array}{l}5.6 \\
\text { SD: } 3.7\end{array}$ \\
\hline Tuber distortion & $\begin{array}{l}14.1 \\
\text { SD: } 22.3\end{array}$ & $\begin{array}{l}4.1 \\
\text { SD: } 5.0\end{array}$ & $\begin{array}{l}4.3 \\
\text { SD: } 1.1\end{array}$ \\
\hline Mechanical injury & $\begin{array}{l}5.6 \\
\text { SD: } 3.7\end{array}$ & $\begin{array}{l}8.3 \\
\text { SD: } 10.1\end{array}$ & $\begin{array}{l}18.3 \\
\text { SD: } 10.4\end{array}$ \\
\hline
\end{tabular}

Table 2. ANOVA and Duncan test (between groups) of differences in external sings at Roclas compared with the other two cultivars during the storage period. Arrows after "p" value show the direction of the main effects: $\uparrow$ indicates higher, $\downarrow$ indicates lower effect.

\begin{tabular}{|l|l|l|l|l|c|c|}
\hline \multicolumn{2}{|c|}{ External signs } & $\begin{array}{c}\text { Sum of } \\
\text { squares }\end{array}$ & df & $\begin{array}{c}\text { Mean } \\
\text { square }\end{array}$ & F & $p$ \\
\hline Silver scurf & Between groups & 7622.22 & 2 & 3811.11 & 13.19 & $0.006 \downarrow$ \\
Roclas & Within groups & 1733.33 & 6 & 288.88 & & \\
& Total & 9355.55 & 8 & & & \\
\hline Wireworms & Between groups & 2084.72 & 2 & 1042.36 & 5.66 & $0.04 \uparrow$ \\
Roclas & Within groups & 1104.16 & 6 & 184.02 & & \\
& Total & 3188.88 & 8 & & & \\
\hline Dried tubers & Between groups & 54.88 & 2 & 27.44 & 5.37 & $0.05 \uparrow$ \\
Roclas & Within groups & 30.66 & 6 & 5.11 & & \\
& Total & 85.55 & 8 & & & \\
\hline
\end{tabular}

Considering the internal symptoms, statistics revealed that tubers did not present most of the pathogens causing severe diseases: bacterial ring rot, late 
blight, potato gangrene, bacterial soft rot, and blackleg were present in very low proportions, much below the infection level. Other problems caused by dry rot, wireworms, black spots, brown spots, and mechanical injuries were present in various proportions (Table 3).

Table 3. The proportions of affected tubers per cultivar observed on the base of internal signs during the storage period

\begin{tabular}{|l|c|c|c|}
\hline \multirow{3}{*}{ Observed internal signs } & \multicolumn{3}{|c|}{ Cultivars } \\
\cline { 2 - 4 } & Christian & Cumidava & Roclas \\
\cline { 2 - 4 } & Mean proportions of the affected tubers (\%) \\
\hline \multirow{2}{*}{ Dry rot } & 1.6 & 3.3 & 15 \\
& SD: 2.8 & SD: 5.7 & SD: 10.0 \\
\hline \multirow{2}{*}{ Wireworms } & 13.3 & 28.3 & 33.3 \\
& SD: 7.6 & SD: 20.2 & SD: 17.5 \\
\hline \multirow{2}{*}{ Black spots } & 1.6 & 5 & 5 \\
& SD: 2.8 & SD: 5.0 & SD: 5.0 \\
\hline \multirow{2}{*}{ Brown spots } & 1.6 & 3.3 & 11.6 \\
& SD: 2.8 & SD: 2.8 & SD: 2.8 \\
\hline \multirow{2}{*}{ Mechanical injury } & 5.5 & 8.3 & 11.6 \\
& SD: 5.5 & SD: 10.4 & SD: 12.5 \\
\hline
\end{tabular}

ANOVA revealed that dry rot causes significantly higher damage in cultivar Roclas (between groups Duncan test, $p=0.01$ ). The Roclas also has a significantly higher proportion of brown-spotted tubers than the other two cultivars (Duncan test, $p=0.05)$. Considering the cumulative data comparisons of external signs, differences in pathogen susceptibility were detected as a significant factor, and the cultivar Roclas presented significantly lower damage. The cultivar Cumidava was less infected by wireworms than Roclas (Figure 1A).

According to the internal signs cumulative comparisons, Roclas presented the highest level of susceptibility to pathogens; this, however, can be attributed to the dry rot that causes higher damage in this cultivar. Wireworms also preferred, in a significantly higher proportion, the Roclas to the Cumidava. Physiological damage was again significantly more frequent in Roclas (Figure 1B).

No significant positive correlations between the plants' vegetative parameters and the most common and dangerous diseases and pests infecting particular plant organs at cultivar Christian were detected (Table 5). There was a significant 
positive correlation between the biomass of the tubers and the silver scurf blemish disease, between tuber numbers and dry rot in cultivar Cumidava (Table 5). There were again significant positive correlations between tuber numbers and the silver scurf blemish disease, between biomass of the tubers and dry rot, and between tuber numbers and wireworm larvae at cultivar Roclas (Table 5).
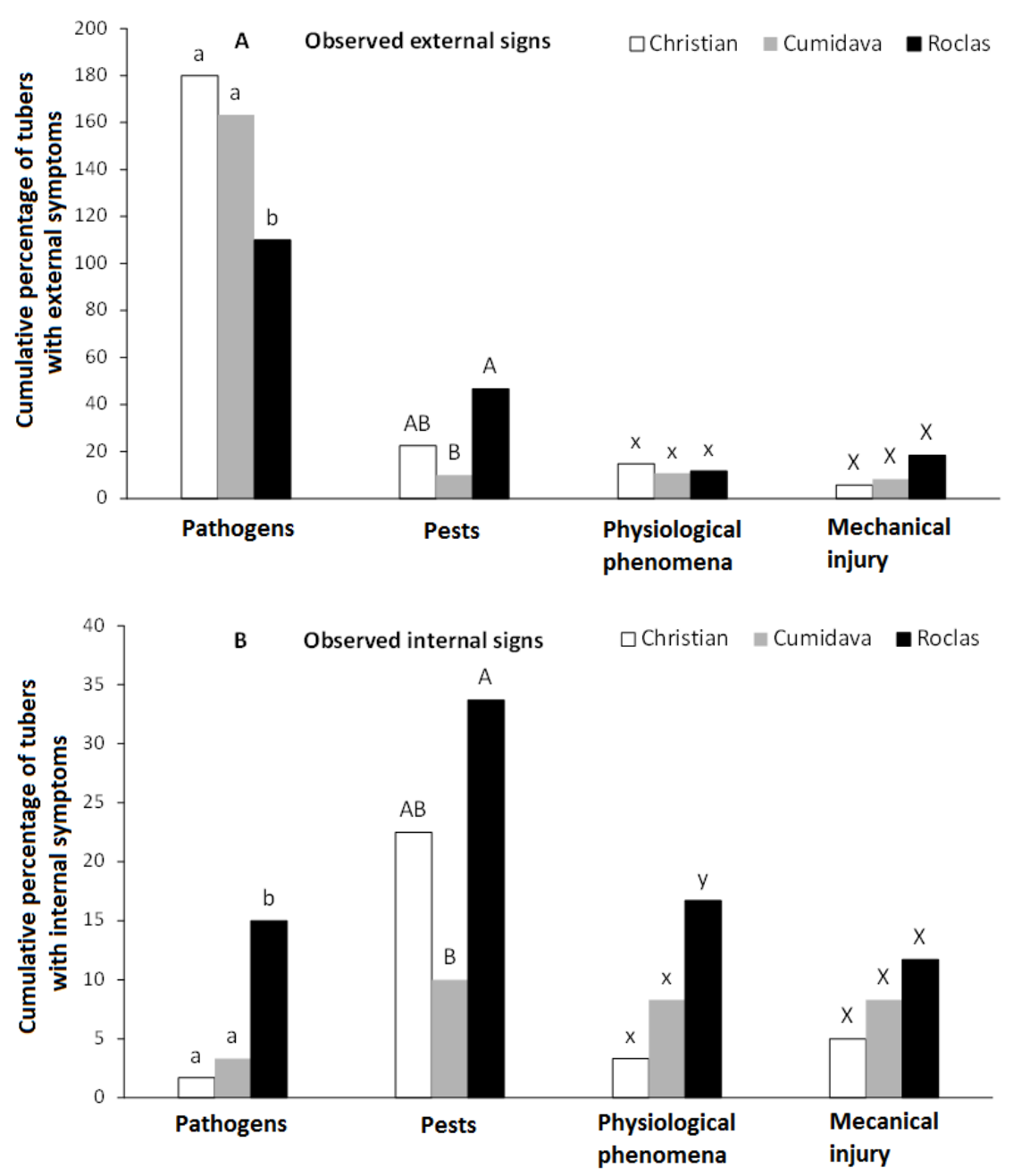

Figure 1. The cumulative sensitivity of the three potato cultivars to pathogens, pests, physiological phenomena, and mechanical injuries by external $(A)$ and internal $(B)$ signs. Different letter $p<0.05$ (ANOVA). 
Table 5. Pearson correlations between the plants' vegetative parameters and the most common and dangerous diseases and pests infecting particular plant organs during storage and vegetation period. Significant differences (rho and $p$ values) are bolded. Plants' vegetative parameters: 1 . Tubers number; 2. Biomass of the tubers; 3 . Nr of leaves at full vegetation; 4 . Nr of shoots at full vegetation; 5 . Biomass of the green part of plants

\begin{tabular}{|c|c|c|c|c|c|c|}
\hline \multirow{3}{*}{$\begin{array}{l}\text { Diseases } \\
\text { and pest }\end{array}$} & \multirow{3}{*}{$\begin{array}{l}\text { Potato } \\
\text { cultivars }\end{array}$} & \multicolumn{5}{|c|}{ Plants' vegetative parameters } \\
\hline & & 1. & 2. & 3. & 4. & 5. \\
\hline & & \multicolumn{5}{|c|}{ rho and $p$ values } \\
\hline \multirow{3}{*}{$\begin{array}{l}\text { Helminthosporium } \\
\text { solani }\end{array}$} & Christian & $\begin{array}{l}0.73 \\
0.47\end{array}$ & $\begin{array}{l}0.81 \\
0.39\end{array}$ & - & - & - \\
\hline & Cumidava & $\begin{array}{l}0.59 \\
0.54\end{array}$ & $\begin{array}{l}0.9 \\
0.01\end{array}$ & - & - & - \\
\hline & Roclas & $\begin{array}{l}0.9 \\
0.05\end{array}$ & $\begin{array}{l}0.89 \\
0.25\end{array}$ & - & - & - \\
\hline \multirow{3}{*}{$\begin{array}{l}\text { Phytophthora } \\
\text { infestans }\end{array}$} & Christian & $\begin{array}{l}0.89 \\
0.19\end{array}$ & $\begin{array}{l}0.09 \\
0.94\end{array}$ & $\begin{array}{l}0.31 \\
0.79\end{array}$ & $\begin{array}{l}0.51 \\
0.65\end{array}$ & $\begin{array}{l}0.16 \\
0.89\end{array}$ \\
\hline & Cumidava & $\begin{array}{l}0.39 \\
0.73\end{array}$ & $\begin{array}{l}0.5 \\
0.66\end{array}$ & $\begin{array}{l}0.46 \\
0.69\end{array}$ & $\begin{array}{l}0.63 \\
0.56\end{array}$ & $\begin{array}{l}0.1 \\
0.93\end{array}$ \\
\hline & Roclas & $\begin{array}{l}-0.38 \\
0.74\end{array}$ & $\begin{array}{l}0.12 \\
0.92\end{array}$ & $\begin{array}{l}0.79 \\
0.41\end{array}$ & $\begin{array}{l}0.35 \\
0.76\end{array}$ & $\begin{array}{l}0.89 \\
0.30\end{array}$ \\
\hline \multirow{3}{*}{ Fusarium ssp. } & Christian & $\begin{array}{l}0.89 \\
0.19\end{array}$ & $\begin{array}{l}0.88 \\
0.94\end{array}$ & - & - & - \\
\hline & Cumidava & $\begin{array}{l}0.99 \\
0.05\end{array}$ & $\begin{array}{l}0.49 \\
0.67\end{array}$ & - & - & - \\
\hline & Roclas & $\begin{array}{l}0.88 \\
0.25\end{array}$ & $\begin{array}{l}0.98 \\
0.05\end{array}$ & - & - & - \\
\hline \multirow{3}{*}{$\begin{array}{l}\text { Larvae of } \\
\text { Agriotes ssp. }\end{array}$} & Christian & $\begin{array}{l}0.22 \\
0.85\end{array}$ & $\begin{array}{l}0.82 \\
0.27\end{array}$ & - & - & - \\
\hline & Cumidava & $\begin{array}{l}0.39 \\
0.73\end{array}$ & $\begin{array}{l}0.5 \\
0.66\end{array}$ & - & - & - \\
\hline & Roclas & $\begin{array}{l}0.9 \\
0.05\end{array}$ & $\begin{array}{l}0.82 \\
0.25\end{array}$ & - & - & - \\
\hline
\end{tabular}


According to our study, common scab affected most of the stored tubers (in a proportion of $86-100 \%$ ) regardless of cultivar. Although common scab did not affect the yield, it greatly reduced tuber quality. Silver scurf was the second disease that appeared in high proportion on the stored tubers. Analysis of external symptoms showed that the quality of tubers was mostly affected by pathogens. The stored tubers were mostly destroyed in a proportion of $13.3-33.3 \%$ by wireworms. If not properly managed during the early growth stage of the crop, wireworms may adversely affect the quantity and quality of the potato yield. The presence of wireworms inside tubers increases the susceptibility to different diseases [15]. Studies have shown that the percentage of injured tubers damaged by wireworms was higher in small tubers than in large ones [16]. In our cases, wireworms were present with no significant differences in all cultivars although tuber biomass was significantly higher in Roclas than in Cumidava. The risk of wireworm damage can be reduced by the rotation of the field, with increasing the number of years between grass clover leys and potatoes [6]. Measuring beetle activity in a given locality should indicate the presence of an established local population, thus contributing to an assessment of the overall risk of wireworm damage [17]. Considering the cumulative data comparisons of external signs, the cultivar Roclas presented significantly lower damages. According to the internal signs cumulative comparisons, Roclas presented the highest level of susceptibility to pathogens; this, however, can be attributed to the dry rot that causes higher damage in this cultivar. Wireworms also preferred, in a significantly higher proportion, the Roclas to the Cumidava. Physiological damage was again significantly more frequent in Roclas. Plant resistance to pathogens and pests can be attributed to physical mechanisms such as skin colour or skin hardness [15]. The results of this study suggest that the two red-skinned cultivars, Cumidava and Christian, show promise as wirewormresistant potatoes.

The three cultivars presented similar characteristics in the growth and development of the above ground vegetative organs at the first two observations. The two medium-early cultivars were advantaged by their shorter vegetation period. There were differences in foliage and tuber reactions to late blight. Considering data from the vegetation period, statistics revealed that potato cultivars present significant differences in susceptibility to late blight disease. Cultivar Cumidava at the first observation period showed a significantly higher proportion of foliage and shoots infected with $P$. infestans than Christian and Roclas. This is because the late-maturing Cumidava was the most exposed to foliage and shoot infection with late blight. Similar studies [18] have noted that the early maturing varieties are more susceptible. Other studies have also reported that the medium and late maturing varieties varied in their resistance levels to bacterial soft rot [19]. These, however, were not demonstrated entirely in our research because, except for late blight, no other differences in susceptibility under field conditions have been 
detected. Using correlations as methods, significant positive relationships between factors (in our case, vegetative parameters and frequency of diseases and pests) can be predicted. In our cases, no significant positive correlations between the plants' vegetative parameters and the most common and dangerous diseases and pests infecting particular plant organs at cultivar Christian were detected. There was, however, a significant positive correlation between the biomass of the tubers and the silver scurf blemish disease, between tuber numbers and dry rot at cultivar Cumidava, between tuber numbers and the silver scurf blemish disease, between biomass of the tubers and dry rot, and between tuber numbers and wireworm larvae at cultivar Roclas. In summary, we can conclude that the most susceptible cultivar was Roclas followed by Cumidava and the least susceptible was the cultivar Christian. Further research, however, is needed to detect if these variations are stable under other climate conditions than Central Europe.

\section{Acknowledgements}

We thank the National Institute of Research and Development for Potato and Sugar Beet, Brașov, Romania for their support. We are also grateful for TransEnglish and David Speight for linguistically reviewing the manuscript. All experiments comply with the current laws of the country in which they were performed. Authors declare no competing interest.

\section{References}

[1] Hooker, J. W. (ed.) (1981), Compendium of potato diseases, The American Phytopathological Society, St. Paul, Minnesota, USA.

[2] Sedláková, V., Dejmalová, J., Doležal, P., Hausvater, E., Sedlák, P., Baštová, P. (2013), Characterization of forty-four potato varieties for resistance to common scab, black scurf and silver scurf. Crop. Prot. 48, 82-87.

[3] Rondon, S. I. (2010), The potato tuberworm: a literature review of its biology, ecology, and control. Am. J. Potato Res. 87, 149-166.

[4] Tatarowska, B., Flis, B., Zimnoch-Guzowska, E. (2012), Biological stability of resistance to Phytophthora infestans (Mont.) de Bary in 22 Polish potato cultivars evaluation in field experiments. Am. J. Potato Res. 89, 73-81.

[5] Rykaczewska, K. (2015), The effect of high temperature occurring in subsequent stages of plant development on potato yield and tuber physiological defects. Am. J. Potato Res. 92, 339-34.

[6] Keiser, A., Häberli, M., Stamp, P. (2012), Quality deficiencies on potato (Solanum tuberosum L.) tubers caused by Rhizoctonia solani, wireworms (Agriotes ssp.) and slugs (Deroceras reticulatum, Arion hortensis) in different farming systems. Field Crops Res. 128, 147-155. 
[7] Runno-Paurson, E., Loit, K., Hansen, M., Tein, B., Williams, I. H., Mänd, M. (2015), Early blight destroys potato foliage in the northern Baltic region. Acta Agr. Scand. B-S P 65(5), 422432 .

[8] Bengtsson, T., Holefors, A., Liljeroth, E., Hultberg, M., Andreasson, E. (2015), Biosurfactants have the potential to induce defence against Phytophthora infestans in potato. Potato Res. 58(1), 83-90.

[9] Russell, G. E. (1978), Plant breeding for pest and disease resistance, Butterworths, London.

[10] Bradshaw, J. E., Dale, M. F. B., Mackay, G. R. (2003), Use of mid-parent values and progeny tests to increase the efficiency of potato breeding for combined processing quality and disease and pest resistance. Theor. Appl. Gen. 107(1), 36-42.

[11] Chiru, S. C., Olteanu, Gh., Asanache, L. E. (2008), History, statistics and trends of the Romanian potato industry. Potato Res. 51, 217-222.

[12] Moldovan, C., Morar, G., Vântă, S., Todoran, F. (2011), Research concerning the influence of photoperiod upon potato stolonization and tuberization. Bulletin UASVM Agriculture 68(1), 224-230.

[13] Moldovan, C., Morar, G., Duda, M., Todoran, C. (2014), Potato tuberization in long photoperiodic conditions. Agricultura - Ştiinţă şi Practică 3-4, 91-92.

[14] Bărăscu, N., Donescu, V., Duda, M., Donescu, D., Ianoși, M. (2014), Preliminary results regarding the effects of extreme climatic conditions on the yield quality of different Romanian potato varieties. Lucr. Şti. Agron. 57(1), 189-194.

[15] Kwon, M., Hahm, Y. I., Shin, K. Y., Ahn, Y. J. (1999), Evaluation of various potato cultivars for resistance to wireworms (Coleoptera: Elateridae). Am. J. Potato. Res. 76(5), 317-319.

[16] Toba, H. H., Turner, J. E. (1981), Wireworm injury to potatoes in relation to tuber weight. $J$. Econ. Entomol. 74, 514-516.

[17] Parker, W. E., Howard, J. J. (2001), The biology and management of wireworms (Agriotes spp.) on potato with particular reference to the U.K. Agric. For. Entomol. 3(2), 85-98.

[18] Tzeng, K. C., McGuire, R. G., Kelman, A. (1990), Resistance of tubers from different potato cultivars to soft rot caused by Erwinia carotovora subsp. Atroseptica. Am. Potato J. 67(5), 287-305.

[19] Reeves, A. E., Olanya, O. M., Hunter, J. H., Wells, J. M. (1999), Evaluation of potato varieties and selections for resistance to bacterial soft rot. Am. J. Potato Res. 76(4), 183-189. 